\title{
A Financial Forecasting Exercise on the Child Restraints Market in the Philippines
}

\author{
Red Thaddeus DP. Miguel, ${ }^{1}$ Wilfrido A. Atienza, ${ }^{1}$ Adovich S. Rivera, ${ }^{1}$ John Juliard L. Go, ${ }^{2}$ Ronaldo O. Quintana, ${ }^{2}$ \\ Kent Jason G. Cheng, ${ }^{1}$ Amelyn A. Mamporte, ${ }^{1}$ Maria Eleanor L. Candelaria ${ }^{1}$ and Hilton Y. Lam ${ }^{1}$ \\ ${ }^{1}$ Institute of Health Policy and Development Studies, National Institutes of Health, University of the Philippines Manila \\ ${ }^{2}$ World Health Organization
}

Key Words: car crashes, car seats, child restraints, financial forecasting, pediatrics, road safety

\section{INTRODUCTION}

The use of child restraints such as car seats or booster seats inevitability increases with the implementation of laws mandating its use in the general public. ${ }^{1}$ This is of great importance to child health and injury prevention as child restraint use has been shown to reduce the risk of serious injury by $71 \%$ to $82 \%$ for children less than 1 year old, and $45 \%$ for children aged 4 to 8 years old., ${ }^{2,3}$ In terms of averting death, child restraints were associated with $28 \%$ reduction in risk for death. ${ }^{4}$ It has been found that using ageand size- appropriate child restraints is the best way to save lives and reduce injuries in a crash. ${ }^{5} \mathrm{It}$ is reasonable therefore, that one study that investigated the association between child restraint law implementation and traffic injury rate among 4 to 6 years old children in New York State found that these children experienced an $18 \%$ reduction in traffic injury rate. ${ }^{6}$

The impact of having laws on child restraints in a country are so significant that even the awareness of impending laws are enough to boost volunteerism and alter the trend of morbidity and mortality among children. Nakahara, Ichikawa, and Nakajima investigated the use of child restraints among pre-school children before compulsory child restraint use for ages $0-5$ years was introduced by the legislative body in 2000 . By collecting police data on child vehicle occupant injuries from 1990 to 2009 and using a join-point regression model, the investigators were able to reveal an increasing trend of morbidity rates by $0.03 \%$ per month $(95 \%$ confidence interval [CI], $-0.02 \%$ to $0.09 \%)$ until the change-point in December 1997 (95\% CI, July 1996 to January 1999), which then changed to a decreasing trend of $-0.14 \%$ per month $(95 \% \mathrm{CI}$, -0.16 to -0.11$)$, with an overall trend change of $-0.17 \%(95 \%$ CI, -0.23 to -0.11$){ }^{7}$ This study showed that even with just an impending law, pre-legislative volunteerism was enough to change the trends in child morbidity.

Republic Act No. 8750 also known as Seat Belts Use Act

Corresponding author: Red Thaddeus DP. Miguel Institute of Health Policy and Development Studies National Institutes of Health

University of the Philippines Manila

623 Pedro Gil Street, Ermita, Manila 1000, Philippines

Telefax: +632 3543832

E-mail: red.upmanila@gmail.com of 1999 , is the country's only law that discusses restraints in cars. However, the law does not mention child restraint use; it merely tackles children passengers' safety through, "Section 5. Children Prohibited to Sit in Front Seat: - Infants and/or children with ages six (6) years and below shall be prohibited 
to sit in the front seat of any running motor vehicle." ${ }^{8}$ It may be necessary therefore to revisit this law, or create child restraints laws considering that just for this year in terms of vehicular crashes there have been 60,583 cases from January to July ${ }^{9}$.

Currently, in the Philippines there are attempts to pass both a House Bill and a Senate Bill that would mandate the use of child restraints in the country. However, this has been faced with opposition from groups stating that the law is anti-poor as only rich individuals will be able to afford child restraints in the Philippines, and therefore those who are not able to afford child restraints are more likely to be apprehended and fined. In an unpublished novel study by Lam et al, it was found that child restraint use in the country was low despite its availability in the market. In this study it was noted that perceived high prices of some child restraint products deter Filipinos from utilizing child restraints. ${ }^{10}$

By virtue of the law of demand and supply, prices can be lower if more suppliers enter the market, assuming all other things equal. Based on the study by Lam et al, ${ }^{10}$ having these child restraints at lower prices will encourage the use of these child restraints by more consumers and can be expected to lower road injuries in the Philippines. Furthermore, lowering the prices will mean that majority of parents who drive 4-wheeled vehicles will be able to afford child restraints. It is therefore hypothesized, that by projecting a scenario wherein there are more distributors, lower prices will be achieved, and hence the proposed laws will find support from the legislators who are currently unsure due to anti-poor ideas being circulated.

\section{MATERIALS AND METHODS}

To test the viability of possible new entrants in the child restraints market in the Philippines, the proponents undertook a financial forecasting exercise to project the financial status and profitability of an archetype child restraint company named Company X.

In order to begin this financial exercise, the proponents identified 4 established companies in the child restraint market in the Philippines from an international list of child restraint companies, the Safe Ride News Publication and the Manufacturers Alliance for Child Passenger Safety Members. Four companies on this list were then identified based on their share of the market and their popularity in shopping malls and online platforms. Together, these four companies make up over $95 \%$ of the current total market. The proponents then obtained their financial statements from the Securities and Exchange Commission for the fiscal years 2012 to 2015.A financial analysis was then undertaken for these companies. The financial analysis included computations for return on equity, net profit margins, and financial ratios. These have been chosen as they give a baseline on the financial condition of these companies and will in turn define whether the companies are financially secure and if they are profitable.
From these statements and analysis, assumptions were added to formulate the financial statements of Company X. Company X's projected financials were then compared against the four currently operating companies, in order to investigate whether a new entrant into the market is sustainable.

\section{RESULTS}

The four companies were labeled Alpha, Bravo, Charlie, and Delta for anonymity. Their income statement's returns on equity were analyzed, specifically, the percentage of profit after income taxes that the companies have earned on their average common stockholders' balances annually. Paid out preferred dividends were deducted from each company's net income. Consequently, in terms of return on equity, company Delta had the highest return at $13.4 \%$, followed by Charlie (2.4\%), then Bravo (1.2\%). Alpha had a negative return at $-1.5 \%$ after all the years were averaged. In terms of the Net Profit Margin of the four companies, Charlie with 1\% had the highest net profit margin, while Bravo had 0.3\%, Delta at $0.2 \%$, and Alpha again was negative at $-0.3 \%$ (Appendix A).

Furthermore, their financial ratios were also deduced to understand the market better. With regard to current ratio, the highest ratio for assets over liabilities was Charlie with 2.7, followed by Bravo 2.2, Delta 0.7, and Alpha had the lowest current ratio at 0.5 . Looking at the asset turnover, or the company's ability to generate sales based on their assets, Delta had a turnover of 5.1, Bravo's turnover was 2.8, Charlie's was 1.5, and Alpha had the lowest turnover at 1.2. In terms of the collection period, the average number of days necessary to convert receivables to cash, Bravo's was a mere 6 days, Delta's was 42 days, while Alpha had the longest at 71 days. Values for Charlie could not be calculated due to lacking entries on their balance sheet. In terms of how long it would take these companies to turn its inventories into sales (inventory days) it was 12 days for Delta, 48 days for Alpha, and 142 days for Bravo. The days payable which shows the complete picture of the companies' turnovers, was as fast as 27 days for Bravo compared to Delta's 80 days and Alpha's 449 days. The financial leverage of the companies, with the use of their debt to equity ratio was analyzed. Delta had the highest debt to equity ratio at 15.4 , followed by Bravo at 0.8 , then Charlie at 0.6, and last was Alpha at -4.9 (Appendix A).

In terms of the revenue growth rate, Alpha had the highest growth rate at $30.0 \%$, Bravo had $13.0 \%$, Charlie had minimal growth rate, and Delta had a decreasing growth rate of $4.0 \%$ (Appendix B).

Given the situation of the Philippine distributors on their financial statements, the investigators then explored how the archetype Company $\mathrm{X}$ will fit in this market with the current players and with a similar environment. Company $\mathrm{X}$ is assumed to be a small to medium sized company entering the market in the National Capital Region (NCR) and distributing through a physical store. These are summarized in Table 1. 
Table 1. Assumptions for Company $X$

\begin{tabular}{|c|c|c|c|}
\hline Assumption & Source & Value & Rationale \\
\hline NCR population growth rate & $\begin{array}{l}\text { Philippine Statistics Office, } \\
\text { release date - } 31 \text { May } 2016\end{array}$ & $1.6 \%$ & $\begin{array}{l}2016 \text { values used as this was the last period of the } \\
\text { financial statements retrieved }\end{array}$ \\
\hline Number of households in NCR & $\begin{array}{l}\text { Philippine Statistics Office, } \\
\text { release date - } 31 \text { May } 2016\end{array}$ & $3,095,766$ & $\begin{array}{l}2016 \text { values used as this was the last period of the } \\
\text { financial statements retrieved }\end{array}$ \\
\hline $\begin{array}{l}\text { \% of households with } \\
\text { children and with car }\end{array}$ & $\begin{array}{l}\text { Philippine National Demographic } \\
\text { and Health Survey } 2013\end{array}$ & $16.0 \%$ & $\begin{array}{l}\text { This was the most recent published Philippine National } \\
\text { Demographic and Health Survey at the time of analysis }\end{array}$ \\
\hline $\begin{array}{l}\text { Number of households in } \\
\text { NCR with car and children }\end{array}$ & Extracted value from NDHS 2013 & 495,323 & $\begin{array}{l}\text { This was the most recent published Philippine National } \\
\text { Demographic and Health Survey at the time of analysis }\end{array}$ \\
\hline $\begin{array}{l}\text { \% of households with } \\
\text { child restraints }\end{array}$ & $\begin{array}{l}\text { Child Restraint Study } \\
\text { by Lam et al, } 2017\end{array}$ & $20.6 \%$ & $\begin{array}{l}\text { Authors are not aware of other data on the assumption } \\
\text { that exists for the Philippines }\end{array}$ \\
\hline $\begin{array}{l}\text { \% of households with car and } \\
\text { children without child restraints }\end{array}$ & $\begin{array}{l}\text { 1- \% of households with CRS, Child } \\
\text { Restraint Study by Lam et al, } 2017\end{array}$ & $79.4 \%$ & $\begin{array}{l}\text { Authors are not aware of other data on the assumption } \\
\text { that exists for the Philippines }\end{array}$ \\
\hline $\begin{array}{l}\text { Number of households that can } \\
\text { still purchase child restraints }\end{array}$ & $\begin{array}{l}\text { Based on NDHS and Child Restraint } \\
\text { Study by Lam et al, } 2017\end{array}$ & 393,462 & $\begin{array}{l}\text { Authors are not aware of other data on the assumption } \\
\text { that exists for the Philippines }\end{array}$ \\
\hline $\begin{array}{l}\% \text { of respondents that } \\
\text { purchase from actual stores }\end{array}$ & $\begin{array}{l}\text { Child Restraint Study } \\
\text { by Lam et al, } 2017\end{array}$ & $38.3 \%$ & $\begin{array}{l}\text { Authors are not aware of other data on the assumption } \\
\text { that exists for the Philippines }\end{array}$ \\
\hline $\begin{array}{l}\text { Number of households that } \\
\text { purchase from stores }\end{array}$ & $\begin{array}{l}\text { Child Restraint Study } \\
\text { by Lam et al, } 2017\end{array}$ & 150,696 & $\begin{array}{l}\text { Authors are not aware of other data on the assumption } \\
\text { that exists for the Philippines }\end{array}$ \\
\hline Market share of the Company $X$ & Assumed & $10.0 \%$ & $\begin{array}{l}\text { Assumed based on possible reach of new company in a } \\
\text { market largely controlled by the } 4 \text { competing companies }\end{array}$ \\
\hline Sales volume & Based on previous assumption & 15,070 & Based on previous assumption \\
\hline
\end{tabular}

Table 2. Financial Ratios of Company X with Alpha, Bravo, Charlie, and Delta

\begin{tabular}{|c|c|c|c|c|c|}
\hline & Alpha & Bravo & Charlie & Delta & Company $\mathrm{X}$ \\
\hline Return on equity & $(1.5 \%)$ & $1.2 \%$ & $2.4 \%$ & $13.4 \%$ & $31.3 \%$ \\
\hline Net profit margin & $(0.3 \%)$ & $0.3 \%$ & $1.0 \%$ & $0.2 \%$ & $6.0 \%$ \\
\hline Operating cash flow (PhP) & $9,431,036$ & $9,867,448$ & $10,324,054$ & $10,801,789$ & $11,301,631$ \\
\hline Current ratio & 0.52 & 2.21 & 2.74 & 0.67 & 2.08 \\
\hline Asset turnover & 1.16 & 2.77 & 1.53 & 5.12 & 3.13 \\
\hline Collection period (Days) & 71 & 6 & - & 42 & 26 \\
\hline Inventory days & 48 days & 142 days & - & 12 days & 73 days \\
\hline Days payable & 449 days & 27 days & - & 80 days & 55 days \\
\hline Debt to equity ratio & (4.89) & 0.74 & 0.56 & 15.38 & 0.68 \\
\hline Current ratio & 0.52 & 2.21 & 2.74 & 0.67 & 2.08 \\
\hline Revenue growth rate & $30.0 \%$ & $13.0 \%$ & $<0.0 \%$ & $(4.0 \%)$ & $4.6 \%$ \\
\hline
\end{tabular}

With the sales volume calculated based on aforementioned assumptions, the selling price per unit was then taken from a scoping study done by Lam et al., 2017. This allowed the investigators to calculate for gross profit, the operating expenses over revenue to calculate for the revenue and a probable operating expense for Company X. Taking all these together, the picture of the income statement was projected to 5 years for Company X (Appendix C).

Having the income statements of the actual companies at hand, the (a) Trade Receivable/Revenue, (b) Inventory/ Revenue, (c) Other Assets/Revenue, (d) Non-current Assets/ Revenue, (e) Accounts Payable/Revenue, and (f) Other Current Liabilities/Revenue ratios were derived. The choice to use Bravo and Delta companies instead of the other 2 (Alpha and Charlie) for the computation of current liabilities was made because they have been in the business longer, they have a more complete financial statement, they possess physical stores where they sell their products, and because Company $\mathrm{X}$ would be catering to the same markets as Bravo and Delta. The balance sheet of Company $\mathrm{X}$ produced from these methods is shown in Appendix D.
Taking then an arbitrary value of $2.0 \%$, Company X's cash statement and balance sheet, a derived common stock of Php 20,684,877.0, an average income of 30.0\%, and an inflation rate of $3.0 \%$ (mid-point of values from the Philippine Development Plan Inflation End-of-plan Target), Company X's cash flow was produced (Appendix E).

Having these projected statements, Company $\mathrm{X}$ was then compared to Alpha, Bravo, Charlie, and Delta (Appendix F). Company X's total current assets were 84.0\%, which was closest to the $94.0 \%$ of Bravo's. Charlie's was 98.0\%, Delta 63.0\%, and Alpha's total current asset was $50.0 \%$. Consequently, for total non-current assets Alpha had $50.0 \%$, Bravo $6.0 \%$, Charlie 2.0\%, Delta 37.0\%, and within the range was Company $\mathrm{X}$ at $16.0 \%$. A total liability for Company $\mathrm{X}$ was $41.0 \%$ and for Bravo it was $42.0 \%$. In terms of equity, Bravo had a vertical count of $58.0 \%$ and Company $\mathrm{X}$ correspondingly had $59.0 \%$.

The financial ratios for Alpha, Bravo, Charlie, and Delta beside the financial ratios of Company $\mathrm{X}$, are presented (Table 2). Company $X$ had the highest return on equity and net profit margin. Company X's return on equity was $31.3 \%$, 
above the $13.4 \%$ of Delta's, which previously was the highest. Likewise, Charlie's $1.0 \%$ which was the highest net profit margin compared to the 4 other companies, was far from Company X's 6.0\%. In terms of current ratio, Company $\mathrm{X}$ at 2.1 fared well among the higher Bravo and Charlie. Company $\mathrm{X}$ ' asset turnover was at 3.1 which came second to Delta's 5.1. Collection period for Company $\mathrm{X}$ was in the middle at 26 days. For Inventory days, again Company $\mathrm{X}$ was somewhere in the middle with 73 days. For days payable Company $\mathrm{X}$ was not far from Delta's 88 days, and Bravo's 27 days. Thus, it can be projected that new candidate companies like Company X in this child restraints market might have a revenue growth rate of $4.63 \%$ per annum.

\section{DISCUSSION}

Based on their financial conditions it is recognized that the companies are in a profitable and financially healthy state. Collectively the child restraint market in the Philippines is stable and has room for growth in the coming years due to a seemingly stable demand for child restraints despite the absence of laws mandating its use.

Currently, because of this stability, companies are able to dictate the prices of child restraints in the country. However, to increase the use of child restraints the prices have to come down in order for more eligible consumers to afford these child restraints. In the results shown, a new company operating at middle capacity and with an average size asset will experience an opportunity for similar growth and profitability with current market leaders. This is promising as this may motivate possible new entrants into the market. Consequently, increasing the number of firms in the market will in turn lower prices of child restraints for Filipino consumers. ${ }^{11}$ Further, with a pending bill on child restraints both in the House of Representatives and in the Philippine Senate it is expected that the demand will rise, enhancing both survival and growth of new firms. ${ }^{12}$

New firms however must be cautioned about rushing into the child restraint market, as current businesses will engage in defensive marketing strategies in order to keep their market share, and profitability. This could include raising barriers to entry such as cornering key markets, product differentiation, hiking capital requirements, limiting access to raw materials and distribution channels, unfair marketing, and others. ${ }^{13}$

In this light, the Philippine government through legislation must proactively encourage new entrants into the child restraint market. It has been found that next to national policies that decrease poverty and increase social equality, the most effective programs for child health promotion and disease prevention, are coordinated policies such as pricing, legislation, and fair market policies. ${ }^{14}$ Failure to do so may enhance the oligopolistic powers of the four existing child restraint companies, which may take this opportunity to actually increase prices. Interviews and discussions with these existing companies revealed that despite the possibility of an increased demand due to the impeding passage of the child restraints law, they do not plan to lower prices, and in fact plan to provide more "better quality" products which they equate with higher prices.

\section{CONCLUSION}

While this provides a cautionary tale that given the status quo of only four players in the child restraints market, the passage of a child restraint law may lead to increased prices. Our financial forecasting exercise provides a ray of hope, that currently operating companies in the child restraint business are stable and enjoy yearly growth, and that new entrants could be both profitable and sustainable, as well. This signals that more companies can enter the Philippine child restraint market, and expectantly this could lower the market price for child restraints and more children can be protected from traffic injuries and death.

It is undeniable that road traffic injuries are a major public health problem, as it accounts for 1.2 million deaths yearly and costing some countries $1-2 \%$ of their gross national product. ${ }^{15}$ With current trends manifesting dramatically increasing trends in road traffic injuries, with the greatest impact on the most vulnerable citizens, appropriate and targeted action is urgently needed. ${ }^{15}$ To combat this, child restraint laws are known to lead to an increased use of child restraint and consequently it is an effective measure to reduce deaths and injuries among children. ${ }^{16}$ It is vital therefore that child restraint legislation be enacted and implemented immediately in the Philippines. In addition, as suggested by the findings of this study, this law should include measures to increase and protect new companies in the market, to ensure that everyone can afford a child restraint and so that consequently every Filipino child travelling in a vehicle will be safer.

\section{Statement of Authorship}

All authors approved the final version submitted.

\section{Author Disclosure}

All authors declared no conflict of interest.

\section{Funding Source}

The study was funded by the World Health Organization.

\section{REFERENCES}

1. Stulginskas JV, Pless IB. Effect of a seat belt law on child restraint use. The American Journal of Diseases of Children. 1983;137(6):582-5.

2. Durbin D, American Academy of Pediatrics. Technical report - child passenger safety. Pediatrics. 2011;127: e1050-66.

3. Arbogast KB, Jermakian JS, Kallan MJ, Durbin DR. Effectiveness of belt positioning booster seats: an updated assessment. Pediatrics. 2009;124(5):1281-6.

4. Elliott MR, Kallan MJ, Durbin DR, Winston FK. Effectiveness of child safety seats vs seat belts in reducing risk for death in children in passenger vehicle crashes. Arch Pediatr Adolesc Med. 2006;160(6):617-21. doi:10.1001/archpedi.160.6.617. 
5. Center for Disease Control and Prevention. CDC study shows that child passenger deaths have decreased 43 percent from $2002-2011$. Center for Disease Control [Online]. February 4, 2104 [cited October 30, 2017]. Accessed from https://www.cdc.gov/media/releases/2014/ p0204-child-passenger-deaths.html.

6. Sun K, Bauer M, Hardman S. Effects of upgraded child restraint law designed to increase booster seat use in New York. Pediatrics. 2010; 126:484-9.

7. Nakahara S, Ichikawa M, Nakajima Y. Effects of increasing child restraint use in reducing occupant injuries among children aged 0-5 years in Japan. Traffic Injury Prevention. 2015 Jan 2;16(1):55-61.

8. Republic of the Philippines. An act requiring the mandatory compliance by motorists of private and public vehicles to use seat belt devices, and requiring vehicle manufacturers to install seat belt devices in all their manufactured vehicles.

9. Medina M. Did you know: road crash cases. Inquirer [Online]; 2016 [cited July 12, 2017]. Available from http://newsinfo.inquirer. net/833560/did-you-know-road-crash-cases.

10. Lam H, Atienza W, Rivera A, et al. Child restraints in the Philippines: a baseline study on the availability, affordability and acceptability of child restraints in the Philippines. Unpublished.

11. Balassa B. Trade, protection and domestic production: a comment. In Kenen B. (ed), International Trade and Finance: Frontiers for Research. Cambridge: Cambridge University Press; 1975.

\section{APPENDIX}

\section{A. Financial ratios}

Financial ratios based on income statement for 4 Philippinebased distributors of child restraint

\begin{tabular}{lcccc} 
& Alpha & Bravo & Charlie & Delta \\
Return on equity & $(1.5 \%)$ & $1.2 \%$ & $2.4 \%$ & $13.4 \%$ \\
Net profit margin & $(0.3 \%)$ & $0.2 \%$ & $1.0 \%$ & $0.2 \%$ \\
\hline
\end{tabular}

Financial ratios based on income statement and balance sheet for 4 Philippine-based distributors of child restraint

\begin{tabular}{lcccc} 
& Alpha & Bravo & Charlie & Delta \\
Current ratio & 0.5 & 2.2 & 2.7 & 0.7 \\
Asset turnover & 1.2 & 2.8 & 1.5 & 5.1 \\
Collection period & 71 days & 6 days & - & 42 days \\
Inventory days & 48 days & 142 days & - & 12 days \\
Days payable & 449 days & 27 days & - & 80 days \\
Debt to equity ratio & $(4.9)$ & 0.7 & 0.6 & 15.4 \\
\hline
\end{tabular}

12. Delmar F, McKelvie A, Wennberg K. Untangling the relationships among growth, profitability and survival in new firms. Technovation, (forthcoming) [Online]. 2012[cited September 20, 2017]. Accessed from http://ratio.se/app/uploads/2014/11/kw_am_fd_wp_205_.pdf.

13. Yannopoulus P. Defensive and offensive strategies for market success. International Journal of Business and Social Science [Online]. 2011 [cited September 27, 2017]. Accessed from http://ijbssnet.com/ journals/Vol._2_No._13_Special_Issue_July_2011/1.pdf.

14. Macfarlane A. What are the main factors that influence the implementation of disease prevention and health promotion programmes in children and adolescents? Copenhagen, WHO Regional Office for Europe (Health Evidence Network report) [Online]. 2005 [cited September 28, 2017]. Available from http://www.euro.who.int/ Document/E86766.pdf.

15. Foundation for the Automobile and Society. Seat-belts and child restraints: a road safety manual for decision-makers and practitioners. London, FIA Foundation for the Automobile and Society [Online]. 2009 [cited October 31, 2017]. Accessed from http://www.who.int/ roadsafety/projects/manuals/seatbelt/seat-belt.pdf.

16. Zaza S, Sleet DA, Thompson R. Review of evidence regarding interventions to increase the use of child safety seats. American Journal of Preventive Medicine. 2001; 21(Suppl. 4):31-34.

\section{B. Growth rate}

Growth rate for 4 Philippine-based distributors of child restraint

\begin{tabular}{lcccc} 
& Alpha & Bravo & Charlie & Delta \\
Revenue growth rate & $30.0 \%$ & $13.0 \%$ & $<0.0 \%$ & $(4.0 \%)$ \\
\hline
\end{tabular}

\section{Income statement of Company X}

Income statement of Company X (2018, 2019, 2020, 2021, 2022) in Philippine pesos

\begin{tabular}{|c|c|c|c|c|c|}
\hline & 2018 & 2019 & 2020 & 2021 & 2022 \\
\hline Revenues & $158,504,808$ & $165,839,459$ & $173,513,514$ & $181,542,679$ & $189,943,385$ \\
\hline Cost of goods sold & $(126,011,322)$ & $(131,842,370)$ & $(137,943,244)$ & $(144,326,430)$ & $(151,004,991)$ \\
\hline Gross profit & $32,493,486$ & $33,997,089$ & $35,570,270$ & $37,216,249$ & $38,938,394$ \\
\hline Operating expenses & $(19,020,577)$ & $(19,900,735)$ & $(20,821,622)$ & $(21,785,121)$ & $(22,793,206)$ \\
\hline Income before income tax & $13,472,909$ & $14,096,354$ & $14,748,649$ & $15,431,128$ & $16,145,188$ \\
\hline Income tax & $(4,041,873)$ & $(4,228,906)$ & $(4,424,595)$ & $(4,629,338)$ & $(4,843,556)$ \\
\hline Net income & $9,431,036$ & $9,867,448$ & $10,324,054$ & $10,801,789$ & $11,301,631$ \\
\hline Beginning retained earnings & - & $9,431,036$ & $10,824,620$ & $12,282,690$ & $13,808,232$ \\
\hline Net income & $9,431,036$ & $9,867,448$ & $10,324,054$ & $10,801,789$ & $11,301,631$ \\
\hline Common dividends & - & $(8,473,864)$ & $(8,865,984)$ & $(9,276,248)$ & $(9,705,497)$ \\
\hline Adjustments & - & - & - & - & - \\
\hline Ending retained earnings & $9,431,036$ & $10,824,620$ & $12,282,690$ & $13,808,232$ & $15,404,366$ \\
\hline
\end{tabular}




\section{Balance sheet of Company X}

Balance sheet of Company X $(2018,2019,2020,2021,2022)$ in Philippine pesos

\begin{tabular}{|c|c|c|c|c|c|}
\hline & 2018 & 2019 & 2020 & 2021 & 2022 \\
\hline \multicolumn{6}{|l|}{ Assets } \\
\hline \multicolumn{6}{|l|}{ Current assets } \\
\hline Operating cash & $3,170,096$ & $3,316,789$ & $3,470,270$ & $3,630,854$ & $3,798,868$ \\
\hline Trade receivables & $11,095,337$ & $11,608,762$ & $12,145,946$ & $12,707,988$ & $13,296,037$ \\
\hline Inventory & $25,360,769$ & $26,534,313$ & $27,762,162$ & $29,046,829$ & $30,390,942$ \\
\hline Other assets & $3,170,096$ & $3,316,789$ & $3,470,270$ & $3,630,854$ & $3,798,868$ \\
\hline Total current assets & $42,796,298$ & $44,776,654$ & $46,848,649$ & $49,016,523$ & $51,284,714$ \\
\hline \multicolumn{6}{|l|}{ Non-current assets } \\
\hline Total non-current Assets & $7,925,240$ & $8,291,973$ & $8,675,676$ & $9,077,134$ & $9,497,169$ \\
\hline Total assets & $50,721,538$ & $53,068,627$ & $55,524,325$ & $58,093,657$ & $60,781,883$ \\
\hline \multicolumn{6}{|l|}{ Liabilities } \\
\hline Accounts payable & $19,020,577$ & $19,900,735$ & $20,821,622$ & $21,785,121$ & $22,793,206$ \\
\hline Other current liabilities & $1,585,048$ & $1,658,395$ & $1,735,135$ & $1,815,427$ & $1,899,434$ \\
\hline Total current liabilities & $20,605,625$ & $21,559,130$ & $22,556,757$ & $23,600,548$ & $24,692,640$ \\
\hline Total liabilities & $20,605,625$ & $21,559,130$ & $22,556,757$ & $23,600,548$ & $24,692,640$ \\
\hline \multicolumn{6}{|l|}{ Equity } \\
\hline Common stock & $20,684,877$ & $20,684,877$ & $20,684,877$ & $20,684,877$ & $20,684,877$ \\
\hline Retained earnings & $9,431,036$ & $10,824,620$ & $12,282,690$ & $13,808,232$ & $15,404,366$ \\
\hline Total equity & $30,115,913$ & $31,509,497$ & $32,967,568$ & $34,493,109$ & $36,089,243$ \\
\hline Total liabilities and equity & $50,721,538$ & $53,068,627$ & $55,524,325$ & $58,093,657$ & $60,781,883$ \\
\hline
\end{tabular}

\section{E. Cash flow of Company $\mathrm{X}$}

Cash flow of Company X $(2018,2019,2020,2021,2022)$ in Philippine pesos

\begin{tabular}{|c|c|c|c|c|c|}
\hline & 2018 & 2019 & 2020 & 2021 & 2022 \\
\hline Net income & $9,431,036$ & $9,867,448$ & $10,324,054$ & $10,801,789$ & $11,301,631$ \\
\hline Add: Depreciation & 0 & 0 & 0 & 0 & 0 \\
\hline Operating cash flow & $9,431,036$ & $9,867,448$ & $10,324,054$ & $10,801,789$ & $11,301,631$ \\
\hline Inc./(Dec.) - Accounts payable & $19,020,577$ & 880,158 & 920,887 & 963,500 & $1,008,085$ \\
\hline Inc./(Dec.) - Other current liabilities & $1,585,048$ & 73,347 & 76,741 & 80,292 & 84,007 \\
\hline Total operating sources & $20,605,625$ & 953,505 & 997,627 & $1,043,791$ & $1,092,092$ \\
\hline Inc./(Dec.) - Trade receivables & $11,095,337$ & 513,426 & 537,184 & 562,042 & 588,049 \\
\hline Inc./(Dec.) - Inventory & $25,360,769$ & $1,173,544$ & $1,227,849$ & $1,284,666$ & $1,344,113$ \\
\hline Inc./(Dec.) - Other assets & $3,170,096$ & 146,693 & 153,481 & 160,583 & 168,014 \\
\hline Inc./(Dec.) - Marketable securities & - & $8,473,864$ & $8,865,984$ & $9,276,248$ & $9,705,497$ \\
\hline Inc./(Dec.) - Non-current assets & $7,925,240$ & 366,733 & 383,703 & 401,458 & 420,035 \\
\hline Total non-operating uses & $7,925,240$ & $8,840,597$ & $9,249,686$ & $9,677,706$ & $10,125,533$ \\
\hline Beginning operating cash & 0 & $3,170,096$ & $3,316,789$ & $3,470,270$ & $3,630,854$ \\
\hline Inc./ (Dec. - Operating cash & $3,170,096$ & 146,693 & 153,481 & 160,583 & 168,014 \\
\hline Ending operating cash & $3,170,096$ & $3,316,789$ & $3,470,270$ & $3,630,854$ & $3,798,868$ \\
\hline
\end{tabular}


Child restraints market

\section{F. Vertical analysis of Company $X$ and 4 Philippine companies}

Vertical analysis of Company X, Alpha, Bravo, Charlie, and Delta

\begin{tabular}{|c|c|c|c|c|c|}
\hline & Alpha & Bravo & Charlie & Delta & Company X \\
\hline \multicolumn{6}{|l|}{ Assets } \\
\hline \multicolumn{6}{|l|}{ Current assets } \\
\hline Operating cash & $15.0 \%$ & $1.0 \%$ & $13.0 \%$ & $2.0 \%$ & $6.0 \%$ \\
\hline Trade receivables & $18.0 \%$ & $5.0 \%$ & - & $44.0 \%$ & $22.0 \%$ \\
\hline Inventory & $10.0 \%$ & $81.0 \%$ & - & $14.0 \%$ & $50.0 \%$ \\
\hline Other assets & $8.0 \%$ & $8.0 \%$ & $85.0 \%$ & $6.0 \%$ & $6.0 \%$ \\
\hline Total current assets & $50.0 \%$ & $94.0 \%$ & $98.0 \%$ & $63.0 \%$ & $84.0 \%$ \\
\hline \multicolumn{6}{|l|}{ Non-current assets } \\
\hline Total non-current assets & $50.0 \%$ & $6.0 \%$ & $2.0 \%$ & $37.0 \%$ & $16.0 \%$ \\
\hline Total assets & $100.0 \%$ & $100.0 \%$ & $100.0 \%$ & $100.0 \%$ & $100.0 \%$ \\
\hline \multicolumn{6}{|l|}{ Liabilities } \\
\hline Total current liabilities & $98.0 \%$ & $42.0 \%$ & $36.0 \%$ & $94.0 \%$ & $41.0 \%$ \\
\hline Non-current liabilities & $28.0 \%$ & - & - & - & - \\
\hline Loans & $28.0 \%$ & - & - & - & - \\
\hline Total non-current liabilities & $126.0 \%$ & $42.0 \%$ & $36.0 \%$ & $94.0 \%$ & $41.0 \%$ \\
\hline \multicolumn{6}{|l|}{ Equity } \\
\hline Share capital & $2.0 \%$ & $26.0 \%$ & $78.0 \%$ & $4.0 \%$ & $37.0 \%$ \\
\hline Deficit & $(28.0 \%)$ & - & - & - & - \\
\hline Retained earnings & - & $31.0 \%$ & (70.0\%) & $3.0 \%$ & $22.0 \%$ \\
\hline Total equity & $(26.0 \%)$ & $58.0 \%$ & $64.0 \%$ & $6.0 \%$ & $59.0 \%$ \\
\hline Total liabilities and equity & $100.0 \%$ & $100.0 \%$ & $100.0 \%$ & $100.0 \%$ & $100.0 \%$ \\
\hline
\end{tabular}

